\title{
VAN HONDERD DICHTERS, ELK EEN GEDICHT \\ Een serie Japanse prenten van Kuniyoshi, Hiroshige en Kunisada
}

In 1986 kochten mijn vrouw en ik - niet gehinderd door enige kennis van zaken - op de Zwarte Markt in Beverwijk onze eerste Japanse prent. Via een boek dat we vonden in de winkel van Van der Peet in Amsterdam kwamen we erachter dat deze prent er één was uit een serie van honderd en het leek ons een interessante uitdaging om te kijken of we nog meer exemplaren van deze serie konden vinden. Zo ontstond een passie voor Japanse prenten die uitmondde in een door Hotei Publishing uitgegeven boek.

\section{Serie van 100 prenten}

In het boek zijn alle 100 prenten van de serie afgebeeld, elk voorzien van een uitvoerig commentaar. De serie is oorspronkelijk op de markt gebracht door de uitgever Ibaya Senzaburô tussen 1845 en 1847 en heeft als onderwerp de 100 beroemdste Japanse gedichten waarbij drie gerenommeerde kunstenaars uit die periode, Kuniyoshi, Hiroshige en Kunisada bij elk gedicht een illustratie hebben gemaakt die gerelateerd kan worden aan het gedicht. Het is nu - na meer dan 150 jaar - een hele opgave geweest om te achterhalen wat de kunstenaar precies in gedachte had toen hij zijn afbeelding maakte, maar dat gold blijkbaar ook voor de kopers uit die tijd want op elke prent staat een nadere toelichting geschreven door Ryûkatei Tanekazu. Overigens, de prenten die in het boek zijn afgebeeld komen niet uit onze collectie maar zijn afkomstig uit een album van de twee jaar geleden overleden Basil W. Robinson, die in zijn boek Kuniyoshi, the warrior prints in 1982 als eerste een beknopte beschrijving heeft gegeven van de hele serie.

Het schrijven van een boek over de serie zou niet mogelijk zijn geweest zonder de inbreng van deskundigheid op velerlei gebieden. Het is de verdienste van Chris Uhlenbeck dat hij die heeft weten te mobiliseren. Hij zette Joshua Mostow en mij op het spoor omdat hij wist dat wij beiden een meer dan normale belangstelling hadden voor deze serie prenten. Joshua Mostow is als Hoogleraar Aziatische Studies werkzaam aan de Universiteit van Brits Columbia in Vancouver, Canada, en hij heeft zich vooral bezig gehouden met de vertaling van de gedichten en het begeleidend commentaar dat op de prenten staat. Ik heb me vooral gericht op de interpretatie van de illustraties, die in veel gevallen - behalve met het gedicht - ook iets te maken hebben met het kabukitheater. Vervolgens hebben we samen bedacht hoe gedicht, commentaar en illustratie aan elkaar konden worden gekoppeld. Daarbij was Joshua's in 1996 gepubliceerde standaardwerk Pictures of the Heart, over de klassieke Japanse poëzie, van onschatbare waarde.

Bij het maken van een Japanse houtsnijprent waren tenminste vier personen betrokken. Een kunstenaar die het ontwerp maakte, een houtsnijder die het ontwerp uitsneed in kersenhouten blokken, een drukker die de blokken met $117 \mathrm{PM}$ verf insmeerde en vervolgens de kleuren overbracht op een vel papien enee access 
- wellicht de belangrijkste persoon van het kwartet - de uitgever die het hele proces superviseerde en financierde. Hij was ook de persoon die in de regel het initiatief nam om aan een bepaalde serie prenten te beginnen en liep daarmee ook het grootste financiële risico. Helaas is van Ibaya Senzaburô, de uitgever van deze serie prenten weinig bekend. Zijn firmastempel komt voor op prenten die zijn gepubliceerd in de periode tussen 1820 en 1850 . Voor 1842 is hij vooral actief bij de productie en verkoop van waaierprenten maar na 1842 gaat hij ook meedoen aan de productie van series prenten in ôban, groot formaat $(24 \times 36 \mathrm{~cm})$. Dit hangt mogelijk samen met het feit dat in 1842 het beschermde gilde van de waaierprentuitgevers wordt opgeheven waarna andere uitgevers ook waaierprenten gaan maken en vice versa.

In ieder geval weten we dat hij in 1845 aan een ambitieus project begint om 100 prenten op de markt te brengen met als thema de 100 beroemde gedichten. Zijn uitgeversstempel, herkenbaar aan de waaiervorm met daarin een cirkel met drie horizontale balken, komt voor in de linkermarge van elke prent.

\section{Economisch risico}

Het idee om in die tijd een serie van 100 dichtersprenten uit te geven was om verschillende redenen een riskante onderneming. Het land verkeerde door misoogsten en slecht financieel beleid in een ernstige economische crisis en leden van de - sociaal gezien - voorname samuraiklasse kwamen in toenemende mate in financiële problemen. In 1842 kondigde de overheid een aantal maatregelen af om de economische crisis te bezweren. Deze Tenpôhervormingen waren onder andere gericht op het intomen van alle vormen van luxe en overdaad. Ook de uitgevers van prenten werden geconfronteerd met een reeks van beperkingen. Zo werd het verboden om nog langer prenten te maken met afbeeldingen van kabuki-acteurs of dames uit de wijken van plezier. Erotische prenten waren al helemaal uit den boze en voor de overige onderwerpen gold dat prenten beslist geen luxe uitstraling mochten hebben en niet meer dan acht kleuren mochten bevatten. Bovendien werden er nieuwe censoren aangesteld om toe te zien op de naleving van de afgekondigde regels. Een andere waarschuwing was dat uitgevers die een paar jaar eerder hadden geprobeerd een serie dichtersprenten uit te geven er niet in geslaagd waren dat tot een goed einde te brengen.

Omstreeks 1835 was de uitgever Nishimura Yohachi in samenwerking met de kunstenaar Hokusai begonnen aan een serie prenten getiteld Van honderd dichters elk een gedicht, uitgelegd door de vroedvrouw. Na vijf prenten werd het project al overgenomen door een andere uitgever, maar ook hij stopte ermee na 22 prenten. Inmiddels had Hokusai al wel 62 ontwerpen gemaakt. Ook de gerenommeerde uitgever Ebisuya Shôshichi was in 1840 - in samenwerking met de kunstenaar Kuniyoshi - begonnen aan een serie dichtersprenten waar de afbeeldingen betrekking hadden op episodes uit het leven van de dichter of direct betrekking hadden op het gedicht. Dat ging aanvankelijk wel goed maar na 58 prenten stopte ook deze uitgever met het project. Ondanks de economische problemen en de slechte ervaringen van andere uitgevers besloot Ibaya Senzaburô om het opnieuw te proberen. Zijn idee was om de 100 gedichten te combineren met historische of legendarische personen. In zijn achterhoofd speelde waarschijnlijk al het idee dat veel historische en legendarische helden ook prominent figureerden in het kabukitheater en dat hij met deze benadering mogelijk de interesse zou kunnen opwekken $v_{2}$ an $_{17 \mathrm{pM}}$ kabukiliefhebbers. 


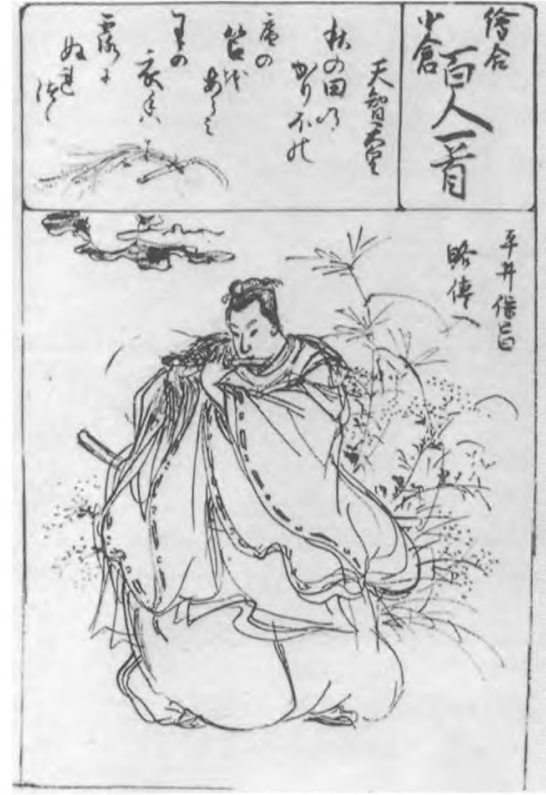

Afbeelding 1

Eerste ontwerp voor de serie. Hirai no Yasumasa speelt op de fluit, p. 22, figuur 7. Door Utagawa Kuniyoshi, c.1844. Museum van Volkenkunde, Leiden

Afbeelding 2

De eerste ook werkelijk gedrukte prent. Prent 1, p. 37. De jonge edelman Ushiwakamaru, de later beroemde Generaal Yoshitsune

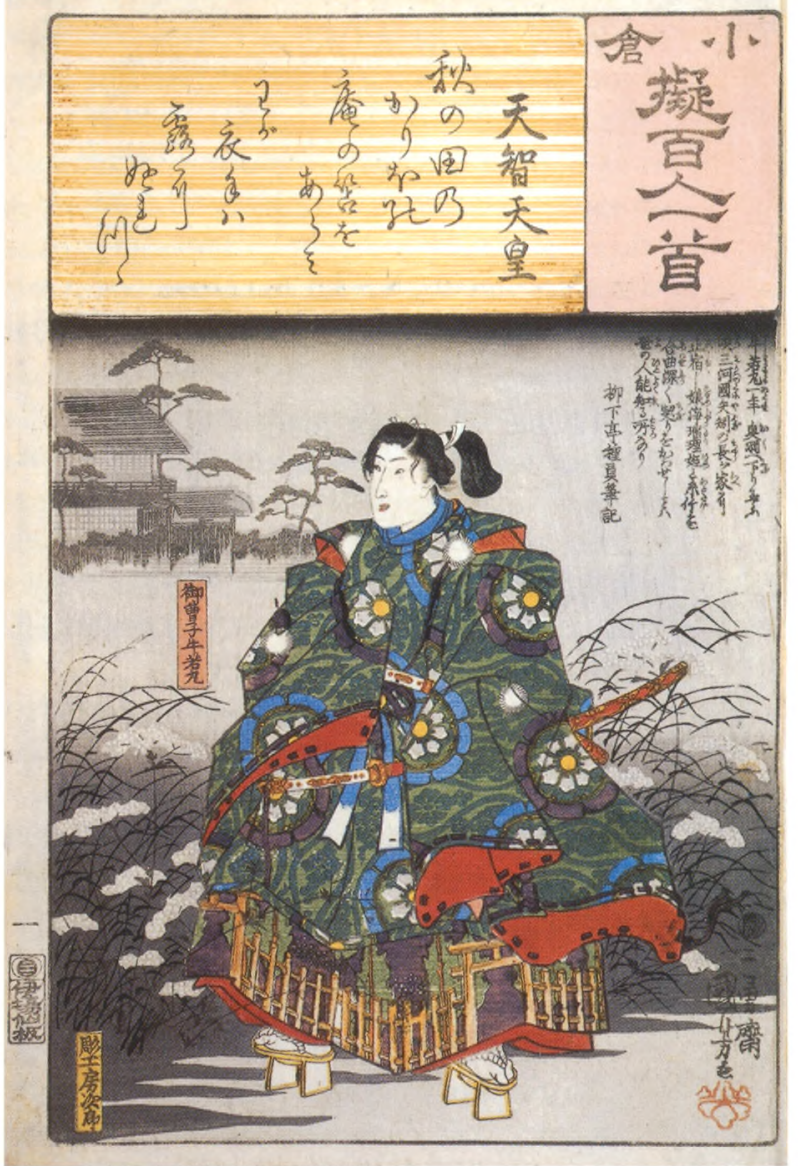

\section{Senzaburô's dichtersproject}

Het lijkt erop dat Senzaburô aan Kuniyoshi heeft gevraagd een eerste opzet voor de serie te maken. Tot onze vreugde bleek een eerste ontwerp voor de serie bewaard te zijn gebleven in het Museum Volkenkunde te Leiden (afb. 1). Vergelijking met de eerste ook werkelijk gedrukte prent laat zien dat er op een aantal punten is afgeweken van Kuniyoshi's eerste ontwerp (afb. 2). De titel is om onduidelijke redenen veranderd van E-awase Ogura hyakunin isshu in Ogura nazorae hyakunin isshu. E-awase betekent zoveel als 'een plaatje gekoppeld aan' en nazorae betekent een parodie, een vergelijking met. Ook de kleine afbeelding onder het gedicht - die verwijst naar het gedicht - is verdwenen. Het meest opvallende is echter dat de persoon die op de ontwerptekening staat, Hirai Yorimasa, de hoveling die met zijn betoverende fluitspel een potentiële dief op andere gedachten weet te brengen, vervangen is door Ushiwakamaru, de later beroemde Generaal Yoshitsune. Mogelijk hangt dit samen met het feit dat de afgebeelde scène betrekking heeft op een liefdesepisode tussen Prinses Jôruri en de jonge Yoshitsune. Dit populajire 2 verhhąal ${ }_{7: 17 \mathrm{PM}}$ werd al in de $14^{\mathrm{c}}$ eeuw door rondreizende blinde zangers - onder begeléiding cess 
van de biwa - voorgedragen. In de loop der tijd is Jôruri een aanduiding geworden voor alle kabukivoorstellingen die begeleid worden door gezongen teksten. Een heel toepasselijk begin dus voor een serie die in bedekte termen verwijst naar het kabukitheater.

Een interessante aanvulling is dat van de eerste prent nog een tweede versie is gevonden. Hierop staat ook de jonge Yoshitsune afgebeeld met op de achtergrond in het gras zijn bediende. Het is weliswaar niet uniek maar wel zeldzaam dat van een ontwerp in een serie verschillende versies zijn gepubliceerd.

\section{De kunstenaars}

Kuniyoshi mag met recht beschouwd worden als de grootste stimulator van het project en hij heeft uiteindelijk meer dan de helft van alle prenten voor zijn rekening genomen. Met zijn reputatie als ontwerper van historische krijgerprenten was de serie hem op het lijf geschreven.

Hiroshige, een leeftijdsgenoot van Kuniyoshi en bekend van zijn succesvolle landschapsseries, was eigenlijk een vreemde eend in de bijt. $\mathrm{Hij}$ had geen noemenswaardige reputatie opgebouwd als tekenaar van helden- of acteursprenten en je zou verwachten dat het publiek vooral zat te wachten op nieuwe series landschapsprenten van zijn hand. Was hij mogelijk even uitgekeken op landschapsprenten? Toch heeft Hiroshige 35 prenten voor de serie ontworpen en de kwaliteit van zijn prenten doet nauwelijks onder voor die van zijn collega's die gespecialiseerd waren in historische en kabukiprenten.

Kunisada was met zijn 59 jaar de oudste medewerker aan het project. Hij heeft slechts 14 ontwerpen gemaakt voor de serie, waarschijnlijk omdat hij tegelijkertijd voor de uitgever Sanoya Kihei bezig was aan een eigen serie van 100 dichtersprenten waar hij de gedichten combineerde met verschillende vrouwelijke bezigheden.

\section{De prent-teksten}

Een interessant en onderbelicht aspect van de prenten zijn de verklarende teksten die waarschijnlijk bedoeld waren om de kopers van prenten op weg te helpen bij het ontdekken van verbanden tussen het gedicht en de afbeelding. Over de schrijver van die toelichtende teksten, Ryûkatei Tanekazu, is helaas weinig bekend. We weten dat hij teksten heeft geschreven voor verschillende geïllustreerde boeken waaronder het zeer populaire verhaal van de Robin Hood-achtige dief, Jiraiya. Blijkbaar kon Tanekazu van schrijven alleen niet leven en moest hij daarnaast in zijn levensonderhoud voorzien door de verkoop van saké, fournituren en boeken, een nogal vreemd aandoende combinatie. Een andere door Tanekazu van commentaar voorziene serie prenten is Kuniyoshi's Taiheiki.

\section{De 100 gedichten}

De leidraad van de serie is de hyakunin isshu, de 100 beroemde Japanse gedichten. De dichtkunst kent in Japan een lange traditie en dichten behoorde met de schilderkunst en de kalligrafie tot de drie favoriete bezigheden. Aan het keizerlijke hof werden dagelijks gedichten gecomponeerd en werden met :17pM grote regelmaat dichtwedstrijden gehouden. De oudste bloemlezing ${ }^{\llcorner} i$ déree $^{-}$access 
Manyôshu - een verzameling van meer dan 4500 gedichten verscheen al omstreeks 785. Aanvankelijk ontstonden deze bloemlezingen door particuliere initiatieven, maar in de $10^{e}$ eeuw ontstond de traditie dat de keizer opdracht gaf tot het opstellen van een nieuwe bloemlezing. Tussen 900 en 1200 zijn meer dan twintig keizerlijke verzamelingen van gedichten opgesteld. Elke verzameling was een afspiegeling van de heersende smaak en werd beschouwd als de nieuwe canon voor de poëzie. Daarnaast ontstonden kleinere verzamelingen die werden gebruikt voor het geven van onderwijs in de dichtkunst. De 100 gedichten-serie is een voorbeeld van een dergelijke educatieve verzameling. Hij is samengesteld door Fujiwara no Teika (1162-1241), een vooraanstaand dichter en kalligraaf uit de Fujiwara familie, die in feite tussen 650 tot 1150 de dienst uitmaakte in Japan. Hij was ook minister van financiën en samensteller van de negende keizerlijke bloemlezing. Het verhaal luidt dat omstreeks 1239 Teika 100 gedichten op speciaal dichtpapier kalligrafeerde en ze vervolgens ter decoratie plakte op de schuifdeuren van zijn villa in Kyoto die uitzicht gaf op de berg Ogura. Deze honderd gedichten zijn bekend geworden als de Ogura hyakunin isshu, 'De Ogura selectie van 100 dichters, elk een gedicht'. Tot op de dag van vandaag wordt deze verzameling gedichten beschouwd als de Japanse codex poeticus.

De gedichten zijn allemaal gemaakt in de periode voor 1239 door personen die deel uitmaakten van de keizerlijke hofhouding in Kyoto. Qua vorm waren het korte gedichten, die in het Japans tanka, waka of uta genoemd worden. Ze bestaan uit 31 lettergrepen verdeeld over vijf versregels. De eerste drie regels hebben een lengte van respectievelijk vijf, zeven en vijf lettergrepen en vormen de inleiding van het gedicht, terwijl de laatste twee regels, die beide uit zeven lettergrepen bestaan, de essentie van het gedicht verwoorden.

De thema's die in de tanka worden beschreven gaan vaak over de natuur, de maan en de wisseling van de seizoenen, al dan niet gecombineerd met menselijke gevoelens zoals melancholie, vriendschap, verdriet, liefde en trouw.

De 100 gedichten waren uitermate populair. Dat komt waarschijnlijk omdat - vergeleken met de zeer omvangrijke keizerlijke bloemlezingen - het een betrekkelijk overzichtelijk geheel was dat uit het hoofd kon worden geleerd. Daarnaast is de grote populariteit ook te danken aan het feit dat de 100 gedichten in de $17^{\mathrm{c}}$ eeuw onderwerp werden van een populair kaartspel, utakaruta, dat vooral op de eerste dag van het nieuwe jaar werd en nog wordt gespeeld. Het spel bestaat uit twee sets kaartjes. Op de ene set staan de eerste drie regels van het gedicht met een afbeelding van de dichter en op de andere set staan de laatste twee regels. De kaartjes met de laatste twee regels worden op de grond uitgespreid en van de andere set pakt de spelleider telkens een kaart die hij dan voorleest of voorzingt. De bedoeling is om dan zo snel mogelijk de kaart met de bijbehorende laatste twee regels te vinden. Op deze wijze zijn Japanners van kind af aan spelenderwijs vertrouwd geraakt met de hyakunin isshu. In de $17^{\mathfrak{e}}$ en $18^{\mathrm{c}}$ eeuw was een dergelijk kaartspel traditiegetrouw een vast onderdeel van de bruidsschat.

Een andere reden voor de populariteit was dat de 100 gedichten regelmatig werden geparafraseerd in schertsgedichten, kyôka. 


\section{Parodieprenten}

In de $18^{\mathrm{e}}$ eeuw komt er een nieuw aspect om de hoek kijken wanneer kunstenaars als Harunobu prenten gaan maken waarbij de 100 gedichten worden gecombineerd met een geheel ander thema, bijvoorbeeld een alledaagse gebeurtenis of een landschap. In dat geval wordt de koper van een prent uitgedaagd om te achterhalen wat beide onderwerpen nu precies met elkaar te maken hebben en wordt een beroep gedaan op zijn kennis van de geschiedenis en klassieke literatuur.

Dit soort combinaties, die in Japan worden aangeduid als mitate-e of parodieprenten waren uitermate populair in de $18^{\mathfrak{c}}$ en $19^{\mathfrak{c}}$ eeuw en Senzaburô's project is in feite een uitgesproken voorbeeld van een dergelijk mitate-serie. Eigenlijk zijn veel prenten uit Senzaburo's dichtersserie dubbele mitate-e omdat de 100 gedichten in eerste instantie worden gerelateerd aan historische of legendarische gebeurtenissen maar daar bovenop kan er ook nog eens een relatie worden gelegd met het kabukitheater.

\section{Van geschiedenis naar het kabukitheater}

De eerste prenten van de Ogura nazorae hyakunin isshu werden gepubliceerd in 1845. Aanvankelijk werd de indruk gewekt dat het ging om een combinatie van de 100 Ogura-gedichten met historische of legendarische gebeurtenissen. Prent nummer $\mathbf{8}$ van de serie is een voorbeeld van een dergelijk historische gebeurtenis (afb. 3). Afgebeeld is Generaal Yorimasa die op punt staat zelfmoord te plegen na een verloren veldslag bij de Uji-brug over het Biwa-meer. Voor hem ligt een waaier waarop hij zojuist zijn afscheidsgedicht heeft geschreven. Dit klopt met de historische feiten en we kennen zelfs de datum van de veldslag en ook van de zelfmoord en de tekst van zijn afscheidsgedicht. In het kabukitheater speelt Yorimasa echter geen grote rol van betekenis. Heel anders is de latere prent nummer 86 van de serie (afb. 4). Daarop staan afgebeeld de bergmonnik Benkei en Shizuka, de minnares van Generaal Yoshitsune. Beide zijn bestaande historische figuren maar de scène die hier is afgebeeld, waarbij Benkei zojuist - uit loyaliteit voor zijn meester Yoshitsune - zijn eigen dochter heeft gedood, is pure kabukifantasie. Bovendien is Benkei afgebeeld met het gezicht van de toneelspeler Nakamura Utaemon IV en is zijn gezicht opgemaakt met rode strepen die je alleen maar tegenkomt in het kabukitheater. Dit is dus geen historische prent, maar overduidelijk een kabukiprent. In de Ogura-serie zie je als het ware de geschiedenis geleidelijk overgaan in de wereld van het kabukitheater.

Nadat de eerste 50 prenten met een overwegend historisch karakter waren gepubliceerd, is de vormgeving van de serie veranderd. De cartouche met de serietitel wordt smaller. Het gedicht wordt in een waaiervormig cartouche - Senzaburô's logo - geplaatst, samen met een afbeelding van de dichter. De toelichtende tekst van Tanekazu verhuist naar het bovenste deel van de prent, waarschijnlijk omdat de tekst vaak gedeeltelijk onleesbaar was door de donkere verlopende kleurband aan de bovenzijde van de illustratie. Bovendien kreeg de kunstenaar hierdoor ook meer ruimte voor zijn tekening. Vanaf prent 52 gaat ook Kunisada meedoen aan het project en wordt er heel systematisch gewerkt.

Zoals al gezegd wordt het kabuki-aspect na prent 50 steeds duidelijker $302: 47: 17 \mathrm{pM}$ Nagenoeg elke prent heeft nu betrekking op het kabukitheater en vaak zijn deess 


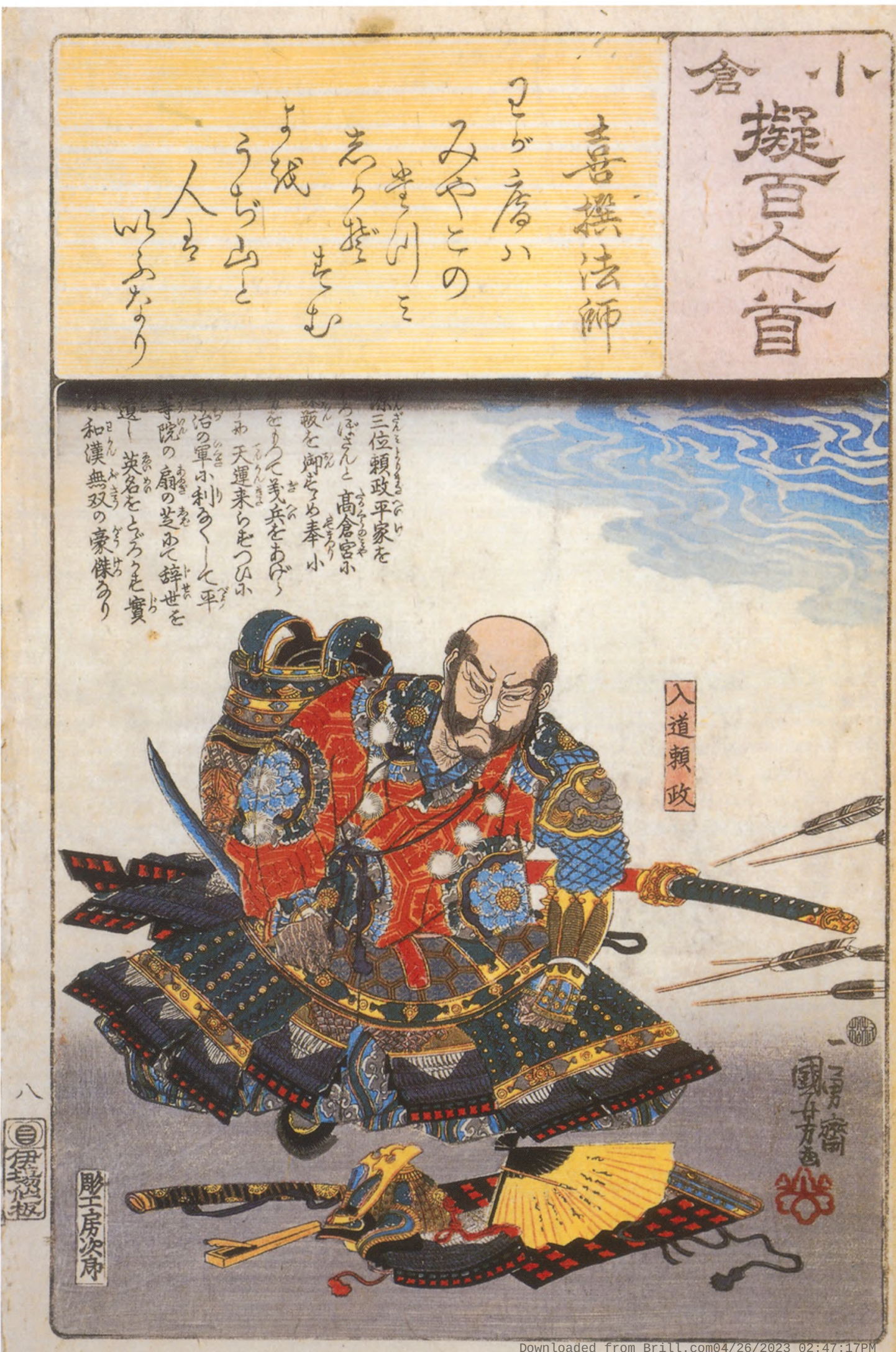




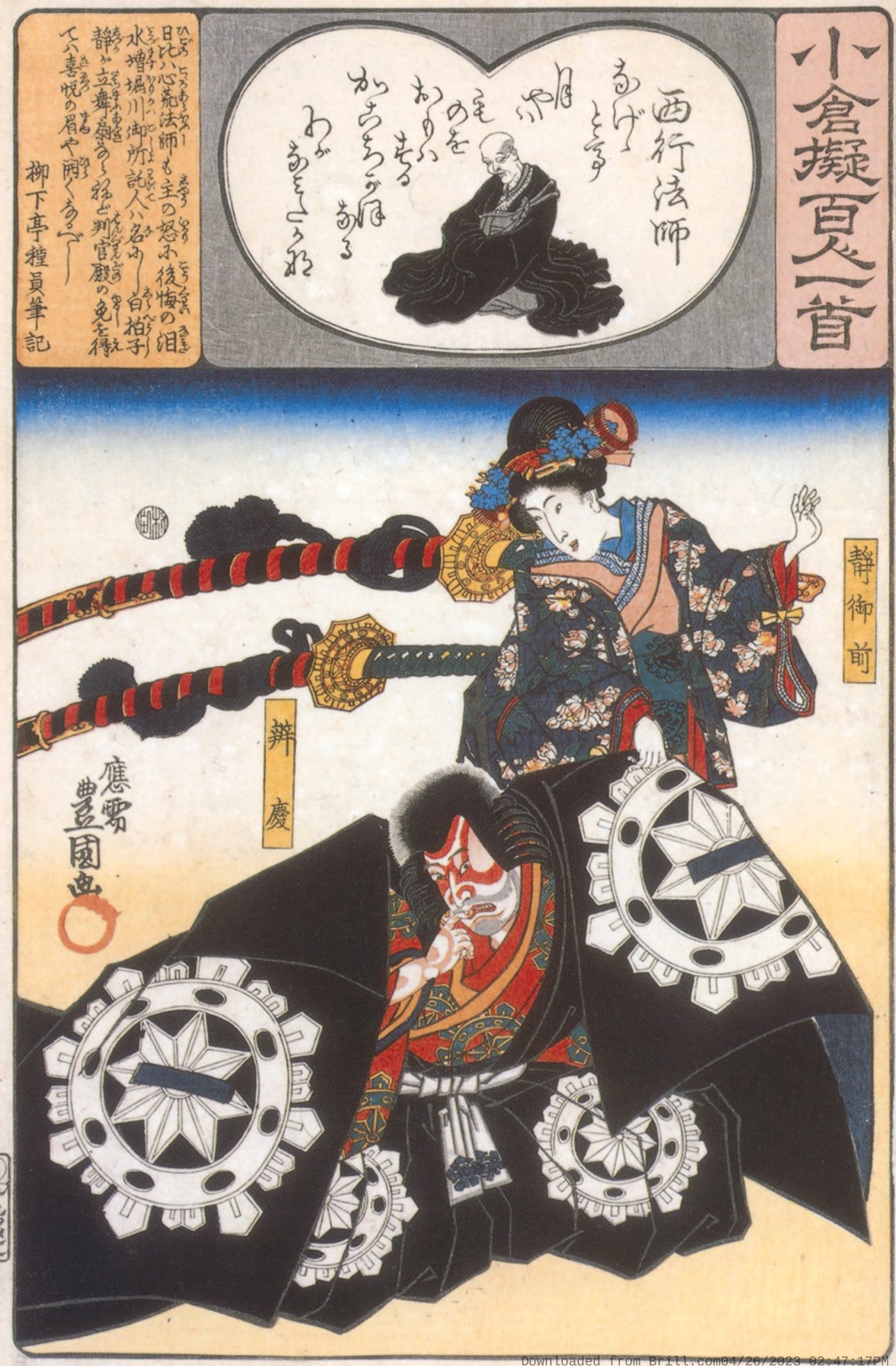


Afbeelding 4 Prent nr. 86, p.207. Door Kunisada. Shizuka Gozen en Benkei

\section{Afbeelding 5}

Prent 9, p. 32, links afgebeeld. Door Hiroshige. Sonobe Saemon. 1846

Afbeelding 6 Prent 9, p.32, rechts afgebeeld. Kabukiacteur Ichikawa Danjûrô VIII als Sonobe Saemon gezichten van de afgebeelde karakters te herkennen als die van populaire acteurs. Weliswaar worden de namen van de acteurs niet op de prent vermeld, maar het moet voor de censors toch duidelijk zijn geweest dat het hier ging om afbeeldingen van kabuki-acteurs. Blijkbaar kende men in die tijd ook al een gedoogbeleid. Stond er geen naam van een kabuki-acteur op de prent, dan was het dus ook geen acteursprent.

Hoe gemakkelijk een historisch onderwerp kan worden omgezet naar een kabukiprent blijkt wel uit de volgende voorbeelden. Op prent nummer 9 is de jonge man Sonobe Saemon afgebeeld onder een bloeiende kersenboom met in zijn hand - heel toepasselijk - een gedicht. Dit is een scène uit de Usuyuki monogatari, een oud Romeo-en Julia-achtig liefdesverhaal met veel trieste verwikkelingen.

In het midden van de $18^{\mathrm{c}}$ eeuw is dit verhaal bewerkt voor het poppen- en kabukitheater, maar op deze eerste versie is het gezicht van Saemon niet te identificeren als het gezicht van een kabuki-acteur (afb. 5). Er bestaat echter een tweede, latere versie waarop duidelijk het gezicht van de populaire acteur Ichikawa Danjûrô VIII is te herkennen (afb. 6). Bij een nadere bestudering blijkt dat uit het oorspronkelijk houtblok een vierkant stukje hout is verwijderd en vervangen door een nieuw blokje met daarin uitgesneden het hoofd van Danjûrô. Waarschijnlijk is de tweede versie gemaakt voor een kabukivoorstelling die in 1847 werd opgevoerd in het Nakamura-theater met Ichikawa Danjûrô VIII als Sonobe Saemon.

Een van de meest gewaagde prenten in de serie is ongetwijfeld prent nummer 56 (afb. 7). Het gedicht is betrekkelijk onschuldig en gaat over iemand die voor zijn naderde dood nog graag eenmaal iemand zou willen ontmoeten. Kuniyoshi heeft bij dit gedicht een illustratie gemaakt van Kagekiyo, een beroemde Generaal van de Taira-clan, die in 1185 in de slag bij Dannoura werd verslagen door zijn aartsvijanden de Minamoto. Hij is op de vlucht, maar in een laatste poging tot wraak vermomt hij zich als een monnik en probeert zijn rivaal Minamoto Yoritomo tijdens de plechtige inwijding van de
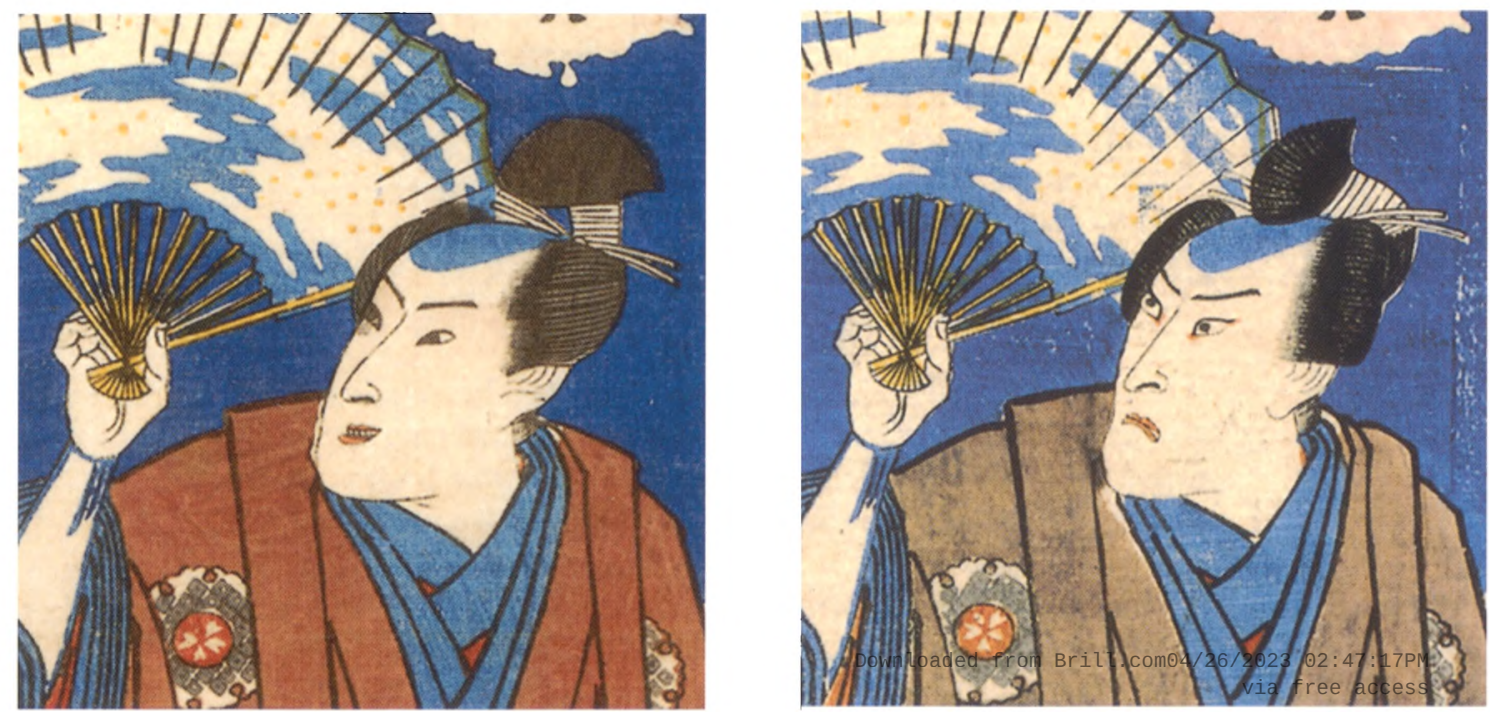

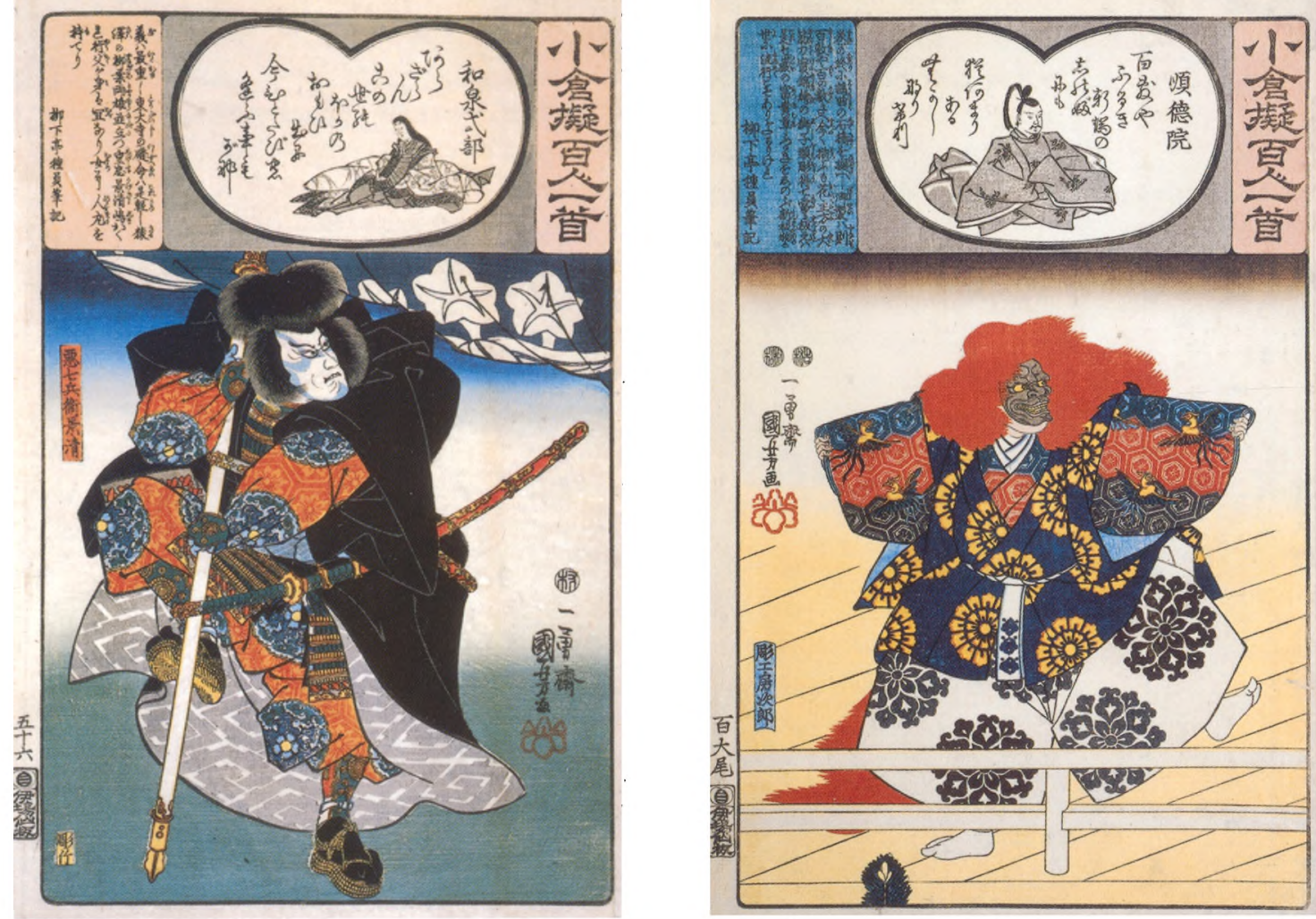

\section{Afbeelding 7}

Prent 56, p. 147. Door Kuniyoshi. Ichikawa

Danjûró VII als Kagekiyo. Kawarazaki theater, 1842

Afbeelding 8

Prent 100, p. 235. De laatste prent van de serie. Door Kuniyoshi.

Een Noh-acteur met een leeuwenmasker en rode manen die de 'stenen brug'-dans uitvoert. grote Boeddha in de Tôdaiji-tempel in Nara met een lans te doden. Helaas voor Kagekiyo loopt deze laatste ontmoeting met Yoritomo - waarop in het gedicht wordt gezinspeeld - uit op een mislukking en wordt hij gevangen genomen.

Veel interessanter is echter dat het gezicht van Kagekiyo lijkt op dat van de in die tijd populaire en ook zeer welgestelde kabuki-acteur Ichikawa Danjûrô VII. ${ }^{1}$ Hij speelde deze rol in 1842 in het Kawarazaki-theater toen hij - in het kader van de Tenpô-hervormingen - tijdens de voorstelling werd gearresteerd. Zijn bezittingen werden in beslag genomen en Danjûrô werd verbannen uit Edo. Dit om aan andere acteurs duidelijk te maken dat de overheid niet gediend was van hun luxueuze levensstijl. Omdat na de Tenpô-hervormingen de acteursprent in een veelal sterk andere vorm terugkwam, is het heel curieus dat de censors deze prent hebben laten passeren.

\section{Afsluiting}

Op de laatste prent van de serie is door Kuniyoshi heel toepasselijk een feestelijke en gelukbrengende leeuwendans afgebeeld (afb. 8). Tanekazu vergelijkt in zijn begeleidend commentaar de succesvolle afronding van de serie met de imponerende leeuwenkop en zegt dat het werk is voltooid door de grote inzet van alle betrokkenen, maar vooral dankzij de uitgever die erin geslaagd is om ook alles te laten uitwerken in houtblokken. Ook bedankt hij het publiek voor de grote belangstelling die zij daebben gehad noor deze $_{02: 47: 17 \mathrm{PM}}$ prenten die teruggrijpen op het verleden. 
Deze serie verdient nog steeds een grote belangstelling - vooral van nietJapans sprekende prentenverzamelaars - omdat deze prenten de kijker en lezer een fascinerende blik gunnen op de Japanse geschiedenis zoals die in het kabukitheater op de planken is gebracht.

- Henk J. Herwig \& Joshua S. Mostow

The Hundred Poets Compared. A Print Series by Kuniyoshi, Hiroshige, and Kunisada Hotei Publishing, Leiden \& Boston, 2007

255 pagina' s, 117 kleurenillustraties

ISBN 978-9074822-824

\section{Noot}

1. Ichikawa Danjûrô VII was de vader van de eerder genoemde Kabuki-acteur Ichikawa Danjûrô VIII 


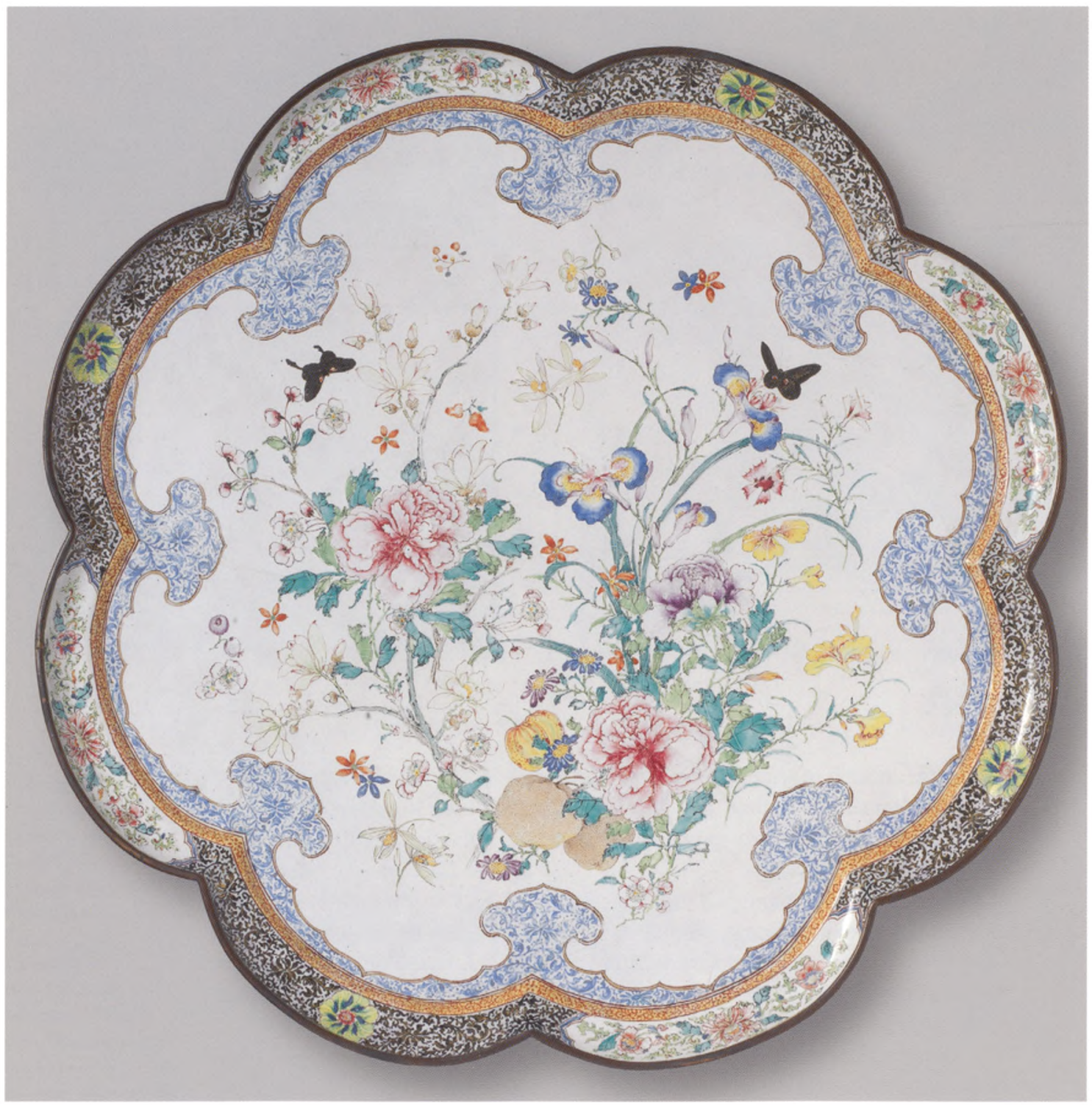

Afbeelding 1

Schotel, emails op

koper, d. $57 \mathrm{~cm}$.,

Kanton, ca. 1730, Rijks-

museum Amsterdam,

AK-RAK-2007-7, aan-

gekocht van de firma

Joseph M. Morpurgo,

Amsterdam 